\title{
事 BeleidsonderzoekOnline
}

Citeerwijze van dit artikel:

Marc Vermeulen, 'Knowhow over het managen van beleidsonderzoek', bso 2012, oktober-

december, DOI: 10.5553/Beleidsonderzoek.000014

DOI: 10.5553/Beleidsonderzoek.000014

\section{Knowhow over het managen van beleidsonderzoek}

\author{
Marc Vermeulen
}

Recensie van het boek Management van beleidsonderzoek. Handreiking voor verdere professionalisering van een dynamisch vakgebied, onder redactie van Bart Dekker, Peter van Hoesel en Yvonne Prince, Den Haag: Boom Lemma uitgevers 2011

In de door Dekker, Van Hoesel en Prince geredigeerde bundel zit vele jaren praktijkervaring op het gebied van het organiseren van beleidsonderzoek samengebald in een toegankelijke en goed gestructureerde tekst. De diverse auteurs, allen afkomstig uit de praktijk, behandelen de meest voorkomende managementthema's in het beleidsonderzoek. Ze beschrijven de aard van het primaire proces, de verschillende soorten markten die bewerkt worden en de wijze waarop dat georganiseerd wordt. Het boek is vooral praktisch van aard en sluit aan bij een reeks eerdere publicaties van (deels) dezelfde auteurs over de ins and outs van het beleidsonderzoek. Hadden eerdere publicaties vooral te maken met de gehanteerde methoden en best practices, dit boek gaat meer over het organiseren van beleidsonderzoek. Voor de auteur van deze recensie is dit geen onbekend terrein. Als lid van het branchebestuur van deze sector ken ik de thematiek en ook een deel van de auteurs en ze zijn zonder uitzondering van goeden huize: betrokken bij het werk van hun eigen bedrijf en dat van de branche, gekwalificeerde insiders dus.

De doelgroep van het boek wordt op de achterflap aangeduid als ' iedereen die op de een of andere manier betrokken is bij beleidsonderzoek: onderzoekers zelf, managers bij onderzoeksbureaus en beleidsmedewerkers die onderzoek begeleiden' en is daarmee wel heel ruim gekozen. In die zin is het boek geslaagd: het biedt een breed overzicht voor een breed publiek.

Ik hoor tot die doelgroep en heb er met belangstelling in gelezen, maar sloeg het boek vervolgens toch enigszins teleurgesteld dicht. Voor mensen die de sector beter kennen, zijn er belangrijkere onderwerpen aan de orde dan die in het boek benoemd worden. Het navolgende stuk is kritisch, maar moet vooral gezien 
worden als een uitnodiging aan de auteurs om nu ook snel deel 2 van dit boek te schrijven met als voorstel 'kritische reflectie op het management van beleidsonderzoek'.

Een eerste kritische kanttekening betreft de selectie van de thema's. Die gaan vooral over de eerste min of meer alledaagse zaken die geregeld en gemanaged moeten worden. Die zijn overigens zeker niet onbelangrijk en worden adequaat beschreven. Beleidsonderzoek is commerciële dienstverlening en die dient goed geolied te verlopen. Uit brancheonderzoek dat de sector regelmatig laat verrichten, komt naar voren dat uitsluitend inhoudelijke kwaliteit zeker niet genoeg is om je te onderscheiden als bureau. ${ }^{\mathbf{1}}$ Proceskwaliteit speelt minstens zo'n belangrijke rol. Beleidsprocessen luisteren vaak nauw en moeten daarin goed en tijdig ondersteund worden. De dynamiek van het beleidsproces moet zorgvuldig gevolgd worden, anders is het mosterd na de maaltijd. Wat me echter opvalt, is de oppervlakkige wijze waarop precies die interactie met het beleidsproces in deze bundel behandeld wordt. Zeker ook vanuit managementperspectief is bijvoorbeeld de vraag aan de orde of het huidige beleidsonderzoek nog wel voldoet dan wel nog voldoende ruimte krijgt. In een periode waarin beleidsprocessen in de samenleving vaak gepolariseerd van aard zijn (denk aan de implosie van het politieke midden) en waarin als gevolg van de langdurige economische crisis mensen in grote onzekerheid verkeren, lijkt er minder ruimte te zijn voor onafhankelijke beleidsmatige analyses. Zijn beleidsprocessen niet meer op zoek naar snelle quick wins en naar oplossingen die wel werken in plaats van analyses waarom iets niet werkt? Mijn waarneming is dat dit een fors managementvraagstuk is, waar ons bedrijf en een aantal collega's mee worstelen. Moeten we als goede schoenmakers bij onze leest blijven, moeten we meer met opdrachtgevers meegaan in hun wensen en verlangens? Dit is op zich geen nieuw thema, maar ik mis het in het boek. Ik zou het toejuichen als de auteurs, die deels ook betrokken waren bij de bundel Beleidsonderzoek in Nederland, ${ }^{\mathbf{2}}$ het in die bundel gekozen bredere perspectief in dit managementboek hadden laten terugkomen als vraagstuk van strategische positionering waarvoor managers van dit type instellingen zich geplaatst zien.

Enigszins gerelateerd hieraan vind ik dat de behandeling van de financieringsvraagstukken in de branche aan de magere kant is en te veel bedrijfseconomisch van aard. Er wordt amper aandacht besteed aan de verschuiving van soorten financiering (bijvoorbeeld meer EU- subsidies), wijzigende concurrentieverhoudingen, kruissubsidiëring en marktvervuiling, het verschil tussen stichtingen en BV's op dit vlak, en de hele discussie over investeringen in ons type werk en de manier waarop je die kunt financieren. Deze meer strategische financieringsvraagstukken worden slechts aangestipt. Met de sombere vooruitzichten over de publieke financiering zullen veel instellingen zich moeten herbezinnen op de strategisch-financiële basis van hun bestaan.

Ook de relatie van de beschrijving met de 'wetenschap' stelde me enigszins teleur. Allereerst wordt er niet ingegaan op een aantal niet onbelangrijke recente discussies in het gehele Nederlandse wetenschappelijke veld. De discussie over kennisvalorisatie komt niet terug, de zogenoemde Veerman-agenda voor het onderwijs evenmin. We lezen niets over de ontwikkeling van lectoraten aan 
hogescholen. Er wordt in mijn ogen een te simpel kennislandschap gepresenteerd met alleen universiteiten en beleidsonderzoeksinstituten, die er met elkaar al een hele tijd niet echt goed uitkomen. De in het boek opgevoerde tegenstelling tussen fundamenteel en toegepast onderzoek zou wel eens achterhaald kunnen blijken, zoals ook de rector van de KU Leuven, Mark Waer, enige tijd geleden opmerkte toen hij sprak over 'nog niet toegepast onderzoek' in plaats van fundamenteel onderzoek. ${ }^{\mathbf{3}}$ Kortom, de wandeling door het kennislandschap, en het zoeken van je plek daarin, gebeurt te oppervlakkig.

Het valt me op dat er relatief veel oude literatuur aangehaald wordt en dat op de gebieden die ik vakinhoudelijk een beetje overzie, er geen sprake is van een state of the art. Op zich is dat begrijpelijk: de auteurs zijn vaak vooral manager van onderzoeksbureaus en in mindere mate vakspecialisten op deelgebieden. Maar de bundel krijgt daarmee het karakter van een samenvatting van wat de auteurs in hun managementpraktijk belangrijk zijn gaan vinden en de boeken die ze daarbij zelf ter hand nemen. Dat is weliswaar praktisch, maar het is daarmee niet noodzakelijk hetzelfde als het weergeven van de huidige stand van het denken over een van de betreffende thema's. Als je besluit een managementboek samen te stellen - en dat verdient waardering - kun je je afvragen of je toch niet een wat grondiger analyse had moeten maken van de laatste stand van het denken, ook al betreft het relatief praktische thema's.

Het geheel overziend wordt de bundel nooit echt spannend. Rondom ons werk zijn veel dilemma's en paradoxen en voor het (strategisch) managen van ons soort instellingen moet je je daartoe zien te verhouden. Het blijft nu te veel hangen in operationele en tactische vraagstukken. Nuttig, maar toch wat onbevredigend. Dit staat ook enigszins op gespannen voet met de ambitie van de bundel. Volgens de flaptekst: 'Managementboeken zijn er genoeg, maar om de inzichten uit die boeken te kunnen toepassen op beleidsonderzoek is een hele vertaalslag nodig. Zo'n vertaalslag wordt in Management van beleidsonderzoek gemaakt.' Ik kan niet zonder meer vaststellen dat de in de bundel beschreven thema's niet ook bij ingenieursbureaus, adviesbureaus of reclamebureaus van toepassing zijn. Natuurlijk zitten er hoofdstukken in die echt met beleidsonderzoek te maken hebben, maar de synthese met de hoofdstukken over algemeen management ontbreekt. Daarmee zou deze bundel wel eens kunnen blootstaan aan dezelfde kritiek die beleidsonderzoek as such ook krijgt: breed maar niet diep, met meer oog voor relevance dan voor rigor,te weinig synthetiserend, en te veel knowhow en te weinig know why.

\section{Noten}

1 De meest recente verkenning is te vinden onder:http://www.beleidsonderzoek.nl/uploads/documents/48.pdf.

2 P. van Hoesel, F. Leeuw \& J. Mevissen (2005). Beleidsonderzoek in Nederland. Kennis voor beleid; ontwikkeling van een professie. Assen: Van Gorcum.

3 Download d.d. 8-7-2012 vanhttp://www.kuleuven.be/openingacademiejaar/o910/toespraken/rector.html. 
(C) Boom Lemma uitgevers 